\title{
SMEs' challenges and needs in relation to innovation agendas and strategies
}

\author{
Åsa Ericson \\ Johan Holmqvist \\ Johan Wenngren \\ Luleå University of Technology \\ Luleå, Sweden
}

\author{
Heidi Kaartinen \\ Centria Research \& Development \\ Ylivieska, Finland \\ Wei Deng Solvang \\ UiT - The Arctic University of Norway \\ Narvik, Norway
}

\begin{abstract}
Regional research project are, as is also regional industry, highly need-based. That is, understanding the stakeholders' (or customers') real challenges and related needs is important. This study is based on interviews with SMEs in the Northern parts of Finland, Norway and Sweden, but also on available innovation agendas and strategies for each country. The differences among the companies in those regions bring forward distinct needs, while many experience similar challenges, for example low population density, long distances and a high dependency on basic industries. Innovation is identified as a key driver of regional growth and competitiveness. SMEs rarely employ the term innovation to describe their activities, but rather stress 'knowing the customer' as important. This indicates one of the challenges to implement innovation strategy as a driver for growth and competitiveness.
\end{abstract}

Keywords-regional; SME; cross-territorial; innovation systems, manufacturing

\section{INTRODUCTION}

EU has since 1990 supported several programs with the intention to support and promote collaboration across territorial boarders. The need that drives the support relates to the necessity to link research and innovation and to deal with the societal challenges. The objective is to increase competitiveness and attractiveness within specific regions, as for example the Northern areas of Finland, Norway and Sweden [1]. These areas are also included in other programs that support peripheral and remote areas on the northern edges of Europe [2]. One basic idea for bringing together those geographically dispersed communities to jointly address growth is that the areas are assumed to have similar threats and barriers, but also it is recognized that innovation is nurtured by integration and shared efforts. In general, the areas are described by having low population density, low accessibility, low economic diversity, abundant natural resources on good and bad, i.e. high impact of climate change [2].

The Interreg program [1] area included 1444515 inhabitants in 2005 (343 146 in Sweden, 638729 in Finland, and 462640 in Norway), in conclusion 3,5 inhabitants per kilometer [3]. Efforts to increase the number of inhabitants in the area have been done, but without great impact and success.
The population in the area is concentrated around a few cities that undergo a small increase of inhabitants, while small municipalities suffer from emigration that makes it difficult to maintain social welfare and services [3]. The sparse population, often consisting of more elderly than young people, makes it difficult for companies to meet the labor needs. The distance between cities across the regions is very long, for example the distance between Kokkola (in Finland) and Tromsø (in Norway) is 947 kilometers, approx. 12 hours by car and 6 hours by plane since the travel goes via one of the capitals. The low accessibility has a direct effect on mobility of labor, on reaching each other's regional markets, and on company collaboration. Compared to more urban areas distances make it not socially sustainable to for long periods of time commute to another city to work on a daily basis, even though some people actually do so.

The previous cross-territorial collaborative Interreg program has been successfully evaluated [4]. Basically, the success depends on assuring that real company situations are addressed in research and development. This means that any research project should conduct one or several participatory stages in their studies, and such a standpoint is not without controversy [4]. From a research point of view this put extra burden to really understand the companies' situations including their challenges and needs, and to over time interact close to companies.

The purpose in this study is thus to explore challenges and needs for SMEs in the Northern parts of Finland, Norway and Sweden. This is done with the objective to identify general concerns, but also to differentiate specific ones for SMEs in the Northern region.

\section{Methodology}

The background for the study presented in this paper originates from three research projects within Interreg North, starting with the project Digital Integrated Manufacturing 2009-2012, Sustainable Manufacturing and Engineering 20122014, and the ongoing project Innovations \& Industrial Internet starting in August 2015 (ending 2018). Cross-territorial collaboration based on identifying common, but also different, 
real industrial challenges and needs is in particular expressed in the current Interreg program [5]. For example, expressing the intentions to as far as possible provide added value in respect of creating transfer and sharing of methods, models, knowledge, ideas and visions across the different areas. Also, a Northern Periphery Arctic program project, i.e. Making regional manufacturing globally competitive and innovative, bring synergies to the study. The latter project encompasses also Ireland and Iceland, yet those parts are not included in this study.

All project work, from this research group's perspective, has had the focus on supporting SMEs within northern parts of Finland, Norway and Sweden. In particular, knowledge transfer and sharing in and between companies provide a perspective. Data and information have been obtained through both informal interactions and previous studies of SMEs in the region throughout all projects' time. Especially for this study in total 18 interviews have been conducted and analyzed. The interviews have been done in SME companies all related to the manufacturing sector, 6 from Norway, 7 from Sweden and 5 from Finland. All interviews followed a settled interview guide, lasted for approximately 1 hour, and were in some cases conducted as a telephone/online interview, to overcome time consuming travels across the regions.

All interviews were guided by a common template, and included questions about the topics:

- Vision, markets, offerings, competition, challenges.

- 5 year strategic plans, trends.

- Technology support, education, competences.

- Planning, design, concept development, production, sales and aftermarket.

The interviews have been recorded and partly transcribed, making it possible to make text analyses. The material has been analyzed by representatives from each country, and aggregated for this study. A so-called SWOT template has been used to support the collaborative analysis. SWOT stands for Strengths, Weaknesses, Opportunities and Treats; the template originates from business administration but is commonly used in all sorts of contexts. SWOT is also commonly used in the programs and agendas included in this study. Its own strength is that it provides a visual possibility to identify strategic issues.

The companies included in this study have in-house product development of products and/or services. The companies have been chosen based on the criteria to represent typical SMEs of each region, but also based on representing typical industrial fields of the region. In short, this means that SMEs in:

- Finland; represents wood, metal and boat industry, welding service and special products manufacturing industry. The smallest firm has less than 20 employees and the largest has more than 150 .

- Norway; represents offshore, fish farming and food industry, mechanical and supplier industries. Most of the firms are micro-sized, i.e. less than 10 employees, but also a large company is included.
- Sweden; represents mechanical and plastic industries, software developers, transmission technology and consumer goods. One large global company has been included to represent the important basic industry in the region. Many SMEs are part of those large companies' supply chains.

The companies are of course regionally located, but act on European and international markets. The organizations within the SMEs, which have more than one employee but less than 10 , usually divide the tasks and responsibilities in broadly defined areas, e.g. CEO, economy (invoicing) and daily operations.

In addition, regional and national innovation agendas, as well as regional and national reports, provide background data for the study.

\section{NATIONAL AND REGIONAL INNOVATION AGENDAS}

The intentions and strategies for supporting national and regional innovation are commonly formalized in reports or agendas that describes a vision and the strategy. The innovation agendas typically describe the reasons why innovation is important by relating the needs to the national challenges. The Swedish and Finnish national agendas explicitly stresses that the many of the challenges are global and that no single actor have sufficient knowledge and resources to solve those [6][7]. Also, the Norwegian innovation report states the crossdisciplinary dimensions of innovation. Oil and gas industry dominates since long ago the Norwegian industry, resulting in high competences related to that type of sector [8]. Yet, the sector is not the largest employer, $87 \%$ are employed in other industries. The Norwegian economy is depending on oil and gas, but knowing that oil and gas are finite resources points toward implementation and support of exploration of innovation opportunities are as a necessity [8].

The concerns of innovation activities at different levels of a society can be summarized from the Swedish agenda (p.5-6) [7] are:

- Meeting the global societal challenges; e.g. climate change, safe and clean energy, green transportation, safe societies, freedom, security participation.

- Creating national competitiveness and employment in a global knowledge economy.

- Deliver direct societal services by quality and efficiency; e.g. health, wellbeing and addressing demographic changes.

The visions described in the innovation agendas can be summarized to address the areas of (a) innovative individuals by increasing competences and skills, (b) improved research and education by increased impact in society, (c) frameworks and structures by norms and markets that sustain innovation, all resulting in innovative companies, organizations, regions and milieus.

The importance to specialize, i.e. make viable choices, on a national level is also addressed, for example the most important 
elements of growth to address for Finland's economy are suggested to be (p.20) [6]:

- ICT skills, mobile solutions and programming.

- Clean solutions, energy efficient, environmentally friendly, material efficient technologies.

- Health and wellbeing.

- Arctic expertise.

A SWOT analysis for the northern areas of Finland, Norway and Sweden during the period 2007-2013 [3] conclude that (p.38):

- Strengths are e.g. strong basic industry, access to natural resources and energy, unique climate conditions, diversity in languages, culture and traditions.

- Weaknesses are e.g. a number of barriers for crossboundary collaboration (language, institutional, mental and so on), small professional milieus at long distance from each other, lack of entrepreneurial and business competences, dependencies on public investments and lack of private financing of research and development.

- Treats are e.g. lack of knowledgeable staff, relocation of companies outside the region, climate change (cold climate is a unique business factor but is now at risk) and increased costs for transportation.

- Opportunities are e.g. new businesses, ecological growth (bioenergy and environmental engineering), active support to promote migration, access to new growth areas.

\section{A. Innovation from a national and regional point of view}

The definition of innovation has an impact on the subsequent execution of actions. However, it is also expressed that capturing the meaning in absolute terms are not useful, rather it delimits the opportunities to address complex challenges. One perspective of innovation on a national level is to explain the phenomena as the creation of new of improved ways to create value for society, companies and individuals, and to stress that the value can be delivered in many shapes, e.g. economic, social or environmental [7]. Regionally, innovation are, besides the broader definition, exemplified as (p4) [9]:

- A new product or service.

- A new process or method to produce a product or a service.

- A new way to organize work, business or relationships.

- A new market or new ways to reach and communicate with actors on a market (users, customers and alike).

- New competences, resources or material.

The national and regional agendas highlight that the innovation systems should support and create a platform for the main actors or networks of innovation activities. The actors can be small and large companies, higher education organizations, agencies and organizations, all interconnected in complex formal and informal networks [9]. That is, cross-boundary and interconnected innovation activities.

\section{CONDITIONS IN THE NORTHERN AREA}

The northern areas of Finland, Norway and Sweden show, despite challenges with demography and geographical location, good conditions for business development. The area follows, respectively, the national level of entrepreneurship/new businesses (metropolitan areas in each region excluded) [10]. Half of the SME business leaders are between 45-60 years old, one quarter is younger than 45 and a quarter is older than 60 . The average SME business leader has a degree from secondary education, 15 years of experience as a business leader and additional 16 years of experience from other positions in business. Education and experiences are similar among SMEs in Finland, Norway and Sweden [10].

In average $10 \%$ of the Swedish and Finnish SMEs business relationships are international, while $5 \%$ of the Norwegian relationships are international [10]. Thus, business relationships for the countries are mainly national, while 9 to $32 \%$ of those are cross-industrial [10].

The ambition to grow is similar among the territorial SMEs, yet the Norwegian SMEs are somewhat less positive to an extensive growth in comparison with the Swedish and Finnish companies [10]. The factors that are important in relation to growth involve everything from the manager's attitude and ambition, to the company's prospects, its business stakeholders and the surrounding community [10]. Yet, several SMEs expressed factors related to the daily operations as a cause for hesitation, for example recruitments, investments, financing and business development. More precisely, they expressed that access to staff with appropriate education, experiences and attitudes are hard, that ambitions to grow require investments/renewal in machinery and/or facilities and that growth demand simultaneous development of offerings [10].

\section{A. Challenges as expressed in the interviews}

The interviewed SMEs in this study express similar challenges as presented in reports from the region e.g. [3][10]. General challenges for SMEs can be summarized as:

- Increased or decreased prices in the basic industry (mining, forestry, oil, fishing) directly affect other industries and their suppliers, i.e. SMEs.

- International companies have larger production volumes and get significant discounts, e.g. on material. Also, due to volumes, they have more effective production lines in comparison to regional SMEs.

- Increasing demands for cost effectiveness of services and products will require investments in digitalization, advanced engineering and tools, and above all skilled workers possessing expertise in those areas.

- Increased competition based on lower prices, i.e. global competition rather than local.

- Increased competition based on growing imports and concentration of markets. 
- Know-how/know-why follows the retiring personnel when they leave the company.

- New ideas, new thinking, rethinking the conventional comes with new staffs, while access to those are limited.

The SWOT analysis from the interviews in this study shows that:

- Strengths are e.g. a high ability to create new products and service, good understanding of existing customers' needs, transparent organizations, motivated to use advanced technology, highly specialized expertise in specific domains.

- Weaknesses are e.g. context (or industry) dependent expertise creates a lack in other areas, low degree of utilizing digitalization, small home markets, lack of marketing and sales expertise for international businesses, high staff turnover mainly for younger personnel.

- Treats are e.g. reducing production costs while maintaining high quality and international competitive products, several product launches per year from competitors causes (rapid) investments in branding, marketing and product development, not sufficient time spent on trend analyses and understanding upcoming customer demands, increased complexity in products.

- Opportunities are e.g. renewal of business by product and service development, outsourcing of production, internationalization, export, increase competitiveness by introducing advanced technology and digitalization (distance spanning), making use of the trainee tradition.

\section{B. Needs analysed from the interviews}

A number of needs can be discussed from the analysis of the interviews with SMEs in the region.

Financing of growth activities is one of the topics that came up. It was expressed that financing organizations in the innovation systems favor academic spin-offs. The support financing is thus dedicated to ideas that might become something in a far future, but seldom supports ideas that can be readily commercialized. Testing an almost ready to launch product at a consumer market has to be paid by the potential business leader. Often SMEs, and in particular micro-sized SMEs lack resources for strategic opportunity explorative (i.e. high risk) projects. This can be described as an identified need to close the gap between spin-off, start-up stages and the actual implementation and commercialization stages.

Growth is a topic that was discussed in-depth. Many of the micro-sized SMEs do not express that they have motivation for growth, in respect of hiring more people. As is, they struggle more or less to manage the daily operations. There are consequently limited resources available to spend on strategy and innovation. Moreover, the term innovation - in the way it is expressed in agendas and definitions - is not part of the SMEs operational vocabulary or mindset. For example, one respondent explained that; "Innovation... it is... I have always tried to improve and to... you know as an entrepreneur you have to be able to live on it, so it is more important to understand market needs".

Among the micro-sized SMEs there is a tendency to act locally in respect of innovation work despite having the customers in other regions. That is, they often support other nearby innovators, while long distance collaboration in these cases would be too costly. Respondents express that collaboration across the northern regions is wanted and also needed, yet it seems like few actors actually include this will in the operational plans. One interpretation could be that intentions will not be realized since time and resources cannot be allocated if there is not a real business proposal as a base. Yet, there are also companies that have acted on remote markets outside their region. The time to travel and low accessibility is clearly expressed as a reason for quitting those businesses.

Some micro-sized SMEs cannot afford to market themselves, and some small SMEs find that allocating money for designing high-quality marketing material is well worth it. Word of mouth is important for micro-sized SMEs when acting on a local home market, for example also a reason to work without payment with innovators. Networking and clustering with other actors become important to access business opportunities. Micro-sized SMEs typically state that their competence is wide, yet mainly within the specialized domain. They use the expression "from wheat to bread" to explain that they support their customers from idea to final product. The need here is to have a long-term and close relationship business model to ensure return of investment. Small SMEs express their development in terms of value creation and specialization. They provide specialized expertise more concentrating towards the core of their own existing businesses, where selling knowledge and competence are an important part. However, business and product development models for delivering products (things, solutions, manufactured goods) exists, but selling knowledge and competence lies outside the active models.

As-is, some companies include knowledge and competence in the product's price. Knowing that they also make the product even more expensive, consequently, they emphasize the need for lowering production and transportation cost. This becomes a kind of a paradoxical situation, a catch-22. Personal engagement, showing readiness to take responsibilities, and creating trust becomes evident in these knowledge-integrated cases. One respondent state that they can, when providing expertise, save a lot of money for the customer, but cannot find out how to bill for the expertise they provide. Still, and related to innovation, the entrepreneurs and business leaders express that they provide, inspiration, ways of thinking and doing that are valuable to their customers, unfortunately often for free.

\section{CONCLUDING REMARKS}

We find that several of the challenges and needs among SMEs in the region on a general level relate to a lack of access to regional resources. Thus, this common issue unites the regions. Cross-boundary collaborations would be a practical and realistic approach to overcome such lack, yet demanding increased utilization of digital solutions beyond information 
technology and conventional technological support systems. Digitalization and Industrial Internet [11], here used as an umbrella term to denote the usage of digital technologies to alter business models and to produce value, is a core concept for providing new products and services. It includes the opportunity to incorporate knowledge driven value creation by using different technologies to increase the value of services in product offerings, e.g. usage of sensor data to offer visual solutions and better maintenance or to offer optimized operations. A key to succeed from digitalization is to have, not only technical expertise but also encompassing skills in innovation work. Preferably, put together into cohesive business and development processes.

If addressing the specific needs among SMEs, we believe that increasing competences in sustainable innovation and product strategies by becoming more confident in utilizing and benefitting from modern technologies will provide skills for commercialization of knowledge integrated solutions. However, it can also be the case that business leaders have good knowledge in how to benefit from adapting old technologies to existing products and production, but limited insights in how to implement new approaches and methods. As a consequence, also they have limited skills of modern product and service development. Being capable to employ such modern approaches instill a cognitive change towards innovative behavior in parallel with the entrepreneurial. In the end, sustaining newer business models for inclusion of knowledge and competence offerings increases competitiveness.

\section{ACKNOWLEDGMENT}

Financing for the Innovations \& Industrial Internet project (I3) from the EU program INTERREG North 2014-2020 that aims to support cross-border collaboration to strengthen competitiveness and attractiveness within the area of northern
Sweden, northern Finland, northern Norway and Sápmi are gratefully acknowledged. Also, TARGET, making regional manufacturing globally competitive and innovative, financed by the Northern Periphery and Arctic Programme 2014-2020 are acknowledged.

\section{REFERENCES}

[1] Interreg North. http://www.interregnord.com/ Accessed 2016-03-29.

[2] Northern Periphery Programme. http://www.northernperiphery.eu/. Accessed 2016-03-29.

[3] Interreg IV A North, European territorial cooperation. Report. Interreg IV A Nord, Europeiskt territoriellt samarbete, rapport. 2007.

[4] Hugosson, J., Olmsäter, T. Hallin, G. Towards a cross-border innovation system in the North, Final Report evaluation Interreg IVA North. På väg mot ett gränsöverskridande innovationssystem i "Nord", slutrapport från utvärderingen av Interreg IVA Nord. Kontigo, 2012.

[5] Administrative County board of Norrbotten, Collaboration program for European territorial cooperation, The official North program. Länsstyrelsen Norrbotten. Samarbetsprogram inom målet Europeiskt territoriellt samarbete, Officiella Nordprogrammet, 2015.

[6] Research and Innovation Policy Council. Reformative Finland: research and innovation policy review 2015-2020. 2015.

[7] Näringsdepartementet. Ministry of Enterprise and Innovation. The national innovation strategy. Den nationella innovationsstrategin, Regeringskansliet, 2012.

[8] Fagerberg, J, Mowery, D., Verspagen, B. The evolution of Norway's national innovation system, Science and Public Policy, 36: 431-444, 2009.

[9] Havnesköld, G., Andersson, P-E., Medelid, C. Innovation strategy for the Norrbotten county 2013-2020. Innovationsstrategi för Norrbottens län 2013-2020. 2013.

[10] Örtqvist, D. Business development in the North program area-an analysis of the growth ambitions, cooperation and export. Näringslivsutveckling i Nordprogramområdet-en analys av tillväxtambitioner, samverkan och export. Länsstyrelsen Norrbotten, 2015.

[11] Evans, P.C., Annunziata, M. Industrial Internet: pushing the boundaries of minds and machines. Imagniation at work, November 26, 2012. 